\title{
The Accountability of the Village Fund Allocation Management at Jenggawah Village, Jember Regency
}

\author{
Dessy Putri Andini \\ Public Sector Accounting \\ Politeknik Negeri Jember \\ Jember, Indonesia \\ bmwsydewi@gmail.com
}

\author{
Arisona Ahmad* \\ Public Sector Accounting \\ Politeknik Negeri Jember \\ Jember, Indonesia \\ arisona_ahmad@polije.ac.id
}

\begin{abstract}
This study aims to identify and assess the accountability of the Village Fund Allocation (ADD) management in Jenggawah Village from the planning, implementation, and responsibility. This research uses a qualitative descriptive study with three data collection techniques, namely interviews, field observations, and document analysis of the Jenggawah Village. The results of this study indicate that in general, the ADD management in Jenggawah Village is accountable, transparent, and participatory. The planning, implementation, and responsibility processes for the management of ADD Desa Jenggawah are following Law Number 6 of 2014, Minister of Home Affairs Regulation Number 113 of 2014, and Regulation of the Regent of Jember Number 37 of 2019. However, there are still constraints in the technical matter. These constraints are internal constraints caused by the lack of knowledge of human resources in managing ADD.
\end{abstract}

Keywords-Accountability, Management, Village Fund Allocation

\section{INTRODUCTION}

The village government is an extension of the central government, which has a strategic role in regulating society. Law Number 6 of 2014 concerning villages has a speciality, namely that it contains a rule that villages will receive financial assistance which will be directly allocated to support the progress of village development. Villages have other rights and powers as a result of tasks imposed by a higher government, namely the right to implement deconcentration, decentralization and assistance tasks in the village [1], [2].

Government Regulation Number 72 of 2005, concerning Villages which explains that the central and regional financial balancing funds received by the Regency / City which in the distribution for each village are distributed proportionally are referred to as Village Fund Allocation (ADD). Village Law No. 6 of 2014 article 72 Paragraph 3 explains that the minimum ADD funds will be disbursed directly to the village as much as $10 \%$ (ten per cent) of the balance funds that will be received by the Regency / City. Village Regulation Number 5 of 2015 confirms that ADD is used as stimulant assistance or stimulant funds to encourage financing of village government administration programs, implementation of development, community development, and community empowerment. The use of Village Fund Allocation requires planning, implementation, supervision, and accountability for its use [5], [6].

Village development planning is inseparable from the scope of the district/city development program, so that village development can still run in harmony with the district/city government because the provision of ADD is a form of trust from the district/city government to the village government as an autonomous region to manage the budget for activities carried out by the village, either in the form of physical activity or not [7]. The government establishes the village as the spearhead of government organizations in achieving success in government affairs. Also, at the planning and budgeting stage, the village government must involve the community so that the programs and activities compiled can be accommodated according to the needs of the village community and according to the capabilities of the village.

The significant role received by the village, of course, is accompanied by a big responsibility as well. The village government must be able to apply accountability in its governance. Accountability is an obligation to convey guilt or to answer and explain a person's performance and actions to parties who have the right or authority to request information and accountability [8], [9]. The level of Accountability in the implementation of ADD management starts from planning, performance, and responsibility [10].

The existence of accountability is vital to the creation of good, democratic and trustworthy governance. The principle of accountability determines that every activity and the final results of these activities must be genuinely accountable to the village community because, in planning and budgeting, the village government must also involve the village community as presented by the Village Consultative Body (BPD).

The fundamental role of Jember Regency in assisting the village government in supporting the development program by allocating an ADD budget of Rp. 285,367,067,000 for 226 villages. Jenggawah Village is one of the villages that also received ADD funds of Rp. 1,262,686,137 for the 2019 fiscal year. This amount is not included in the nominal amount that is considered small for the implementation of the village development program so that it is the background for the author to know more about the planning and implementation of Jenggawah Village in managing the Village Fund 
Allocation (ADD) for the 2019 Fiscal Year. The purpose of this research is to find out and analyze what activities have been implemented by the Village Government of Jenggawah in implementing and managing the Village Fund Allocation (ADD).

\section{METHOD}

This research uses the descriptive qualitative method. The researcher tries to describe the actual picture according to the phenomenon that occurs in the management of the Village Fund Allocation (ADD) for the 2019 Fiscal Year in Jenggawah Village, Jember Regency. This method is done by collecting, preparing, and analyzing data so that you get a clear picture of the problem being studied.

The data collection techniques used were interview techniques, direct observation, and document analysis of the village of Jenggawah. Interviews were conducted, namely by giving open questionnaires to selected respondents for specific reasons, which meant that the parties were directly involved in the management of ADD. We then call these respondents as informants who will assist researchers in obtaining information about the planning process to accountability in managing ADD in Jenggawah Village.

Then performed data reduction as a process of simplifying the data obtained during the interview. Data triangulation was carried out to unify and compare the data that the informants had obtained so that the data was valid. The final step is concluding the data that has been analyzed to get the final result of the study.

\section{RESULTS}

\section{A. Planning}

The planning process is the initial stage in village financial management. At the planning stage, the village government will compile programs and activities to be implemented during the year concerning determining priority scales. The planning process at Jenggawah Village begins with holding a Hamlet Deliberation (Musdus) by the Minister of Home Affairs Regulation Number 113 of 2014 which states that the planning process will begin with the procurement of a Hamlet Deliberation (Musdus) to accommodate the aspirations of the community in each RT and RW. Jenggawah Village carried out the hamlet deliberation process which was carried out only in each hamlet internally, which would then be presented at the Musdes, this was explained by Informant 1:

"There is a Musdus, but our range does not go directly to each hamlet, so the hamlet itself, namely kasun and RT $R W$, conducts musdus internally before it is presented to the community. For community participation, so every community has a representative, the term delegation to convey aspirations on behalf of RT and RW."

This opinion is supported by informant 2 statement, which explains that:

"The number of hamlets in this village is seven hamlets, so if we do musdus in each hamlet, it will take a lot of time, not to mention the large number of RT RWs so that many residents want to participate in giving aspirations. We discussed determining the program. Therefore we only asked each kasun (a leader of a sub-village) for help to discuss the program if it is a priority and is needed in each hamlet."

In the planning process, Jenggawah Village carried out a planning process based on the RKP adopted from the RPJMDesa in 2019 according to Jember Regent Regulation Number 37 of 2019 concerning Procedures for Distribution, Determination of Details and Guidelines for the Management of Village Fund Allocation in Jember Regency for the 2019 Fiscal Year which explains that the planning of activities financed by ADD is guided by the RPJMDesa and RKPDesa documents which will then be discussed at the Musdes. This was explained by Informant I statement:

"Our planning begins with the RKP, but because in 2019 the RPJMDes already exists, so we adopt the RPJMDes to the RKP, in the previous year we had planned the RKP for 2019, it was done to carry out plans that discussed what we would build, activities whatever we will do, then we will do the RKP musdes."

Village Deliberation (Musdes) is an annual discussion forum of village stakeholders to agree on action plans for the next fiscal year. Musdes is guided by the principles of the Village Community Participation Development Planning (P3MD). This principle requires community participation in the implementation of planning so that the village government can accommodate what the community needs according to the aspirations given by the community or residents. Thus, it is hoped that the village government can respond to the needs of residents to form more developed villages.

At the musdes implementation stage, the village government of Jenggawah will always work together with the BPD to provide direction to community institutions with interest as well as several community leaders to always actively participate in conveying their aspirations. This was explained by Informant 1:

"For Musdes participants, we have the village head and his apparatus, then BPD, assistants, then there is also the kasun and the RT and $R W$ but not all, we limit each hamlet to three or four RT as regional representatives, because it is not possible if we all participate, we have seven hamlets, $12 \mathrm{RW}$ and $97 \mathrm{RT}$, we should be able to bloom this hehe."

The village head of Jenggawah explained that the Musdes in 2019 was not focused on infrastructure development:

"To focus on 2019, the infrastructure development is not, in 2019 we only allocate 62 million for the renovation of the pavilion, because yesterday the ADD had increased, from 900 million to 1.26 so. So the rest of the budget is related to activities that are not carried out, for example, the income for Kasi Kesra because the young man died, instead of becoming a year-end SILPA, it is allocated for this renovation combined with the remaining use of other funds, so we found that 62 million of funds were the renovation of the pavilion and yesterday there were also residents' aspirations to repair the hamlet gate, so yeah we allocate it for that."

Jember Regent Regulation Number 37 of 2019 concerning Procedures for Distribution, Determination of Details and 
Guidelines for Village Fund Allocation Management in Jember Regency for Fiscal Year 2019 explains that the programs to be financed by ADD are focused on activities in the field of village administration, the field of implementing village development, the field of guidance community, community empowerment sector, and disaster management, emergency and urgent situations. This is what underlies the planning of Jenggawah Village in 2019 not to focus on infrastructure development but rather prioritizing community development and empowerment as described by Informant 2:

"For the guidance and empowerment of the community, yesterday we had our posyandu guidance, there was providing additional food for pregnant women, toddlers, then posyandu for the elderly, there were activities related to improving nutrition, then our coral reef activities supported the request for loudspeakers at that time, so we provide, then there is also a healthy community movement, we do anjangsana (meaning visit each other) which is accommodated by PKK mothers to do gymnastics every Friday. For community development there are PKK activities, once a month LKD coaching is focused on LPM, our Karangtaruna guidance supports what the youth organization needs, then there is also coaching for members of linmas (meaning community protection)."

The essential principle of implementing musdes is participation. Jenggawah Village has embodied these principles. The implementation of the principle of participation can be seen in the enthusiasm of the residents in participating in the implementation of the Musdes; the Informant's statement supports this:

"For this citizen participation, I think it is excellent, sis. Because without even being asked, the residents are always happy to participate in the process or take part in the programs to be implemented by the village government. So, the role of the residents here is also to be a supervisor in the running of the existing program, miss, especially our program is self-managing, sis, so these residents are enthusiastic about helping, for example in the procurement of goods, if there is repairing the gate or what is it, the residents help find-looking for the material, take it here or there, sis."

From the information above, it can be seen that the enthusiasm for the participation of the residents of Jenggawah Village is excellent. When they get word from the Hamlet Head regarding the implementation of the Musdes, they will be happy to offer to become Musdes participants. The Village Government also supports the enthusiasm of the residents by providing opportunities for residents who will take part in the Musdes forum, according to Informant 1 statement:

"I support the enthusiasm of these residents, sis, because yes, community involvement is also an important point, we never close, are always open, whatever our activities are we don't choose who has the right to participate, so we coordinate with Kasun to ask for help in case of this."

In terms of transparency of deliberation results related to planned programs and activities, Informant 1 explained that every Musdes had been implemented there will be an official reading of the Musdes results so that all Musdes participants can know the results and decisions of the Musdes results. According to informants who have interviewed researchers, the results of the musdes which are then determined through the Perdes will be displayed on a banner that will be placed in front of the village office pavilion. Unfortunately, the researcher could not find evidence of the banner on the front page of the village office pavilion, and a copy of the minutes that could not be obtained for additional interview data. According to Informant 1 , the banner collapsed a few weeks ago so that the banner was absent and the transparency banner was only in the village office, not in each hamlet. Informant 1 statement is consistent with the statements of several other informants who stated that the transparency banner had collapsed some time ago.

\section{B. Implementation of Village Fund Allocation (ADD)}

The implementation stage of ADD fund management is carried out by the Village Financial Management Technical Implementer (PTPKD). Based on the results of interviews with the village head, the PTPKD in Jenggawah Village, namely the village secretary as the PTPKD coordinator, the section head as the executor of the activities, and the head of finance as the holder of financial affairs.

In Jenggawah Village, the activity implementation team is directly handled by the head of the section and the head of affairs of each activity as the coordinator, but in field implementation, the structural roles of each head and head have not been going well. This was explained by Informant 1:

"The implementation should have been supervised by the section head and head of respective affairs. But what seems to be running is more of a government and development sector activity, yeah, what I think is going well, because in this case the government sector, for example, the government itself is the executor of the activities, the process is like what I have said, everything is carried out through payment order."

This structural inconsistency is due to the fact that each human resource has minimal knowledge so that each activity and program is still supported by other Kasi and Kaur in terms of implementation. This is supported by the Informant 2 statement:

"The problem is internal, miss, maybe HR is not the same. What do you want to do? For example, when they want to be forced to follow a fast process, sometimes it is the HR constraints. If it is implemented, it is very supportive of the outside. Because people are the ones who support and naturally want to finish quickly, so they participate in the implementation."

From the statement above, the implementation of the program from Jenggawah Village is under Law Number 6 of 2014 which states that the implementation of development funded by ADD must involve the community and seek more labour absorbed from the local village community.

The Village Government also carries out the implementation of Law Number 6 of 2014 in the procurement of goods and services in implementing programs and activities. The Jenggawah Village Government will maximize the goods needed by utilizing the village wealth as the main 
ingredient. Likewise, with service procurement, the village government will maximize residents to participate in the implementation. This was explained by Informant 1:

"All activities in our village are self-managed, so the matter of procuring goods and services will be commanded by the relevant head and chief. The implementation problems below, we are assisted by $\mathrm{Mr}$ Kasun for the implementation. Furthermore, Mr Kasun will be formed like a forum called TPK, which is assisted by one member of the LKD, in this case, the LKD is from the community empowerment institution or LPM, and one from community leaders or youth leaders. So, especially in infrastructure development, we involve the community directly in its implementation. For example, in the procurement of goods, if we have it in a village, we will not collect it from another village, such as sand mining, there are many sand mines, we will take it there, just like materials, we take construction materials from shops in our village. But it is limited to two years, so if two years in a row we take it in Person A, the next two years we move to Person B, like that, so there is even distribution. The provision of services is also the same; we took the workers from the relevant hamlets, and focused on the RT $R W$ that was close to the activity."

In administration, Jenggawah Village uses the Village Financial System (SISKEUDES), but in field implementation, Jenggawah Village still often uses manuals because they often experience difficulties in using the system. This was explained by the informant 2 :

"For administrative records, we use the siskeudes system, but we are still in the learning process, we are still asking this to friends, to assistants, to TPK, to make it a guide for the implementation of accountability for funds in the village. Because in practice, we still often experience difficulties in the system of siskeudes itself, sis. Yes, the system is sometimes inflexible, so if there are changes, it is usually difficult."

In carrying out TPK activities, Jenggawah Village makes expenditures for goods and services needed to carry out work programs using a Payment Order Letter (SPP). SPP is a document that contains requests for payment or approval of expenditures that have been carried out by the activity implementer, verification documents by the village secretary, as well as expenditure approval documents by the village head as well as orders for the village treasurer. After receiving the goods and services, the TPK is obliged to deposit the SPP to the treasurer, then verified by the village secretary and then approved by the village head. SPP is an essential document in preparing the realization of accountability, all SPP activities, at the end of the period will be compiled to find out the accumulated expenditure for each activity [12].

Jenggawah Village implements the mandate written in the Minister of Home Affairs Regulation Number 113 of 2014. This was explained by Informant 1:

"ADD itself, it just so happens that ADD is more than binding spending, so we do a payment request mechanism first from the head of the government, then from the head of the office submits a payment request letter to the treasurer, verified by the village secretary, after that the village head approves it, then we make a payment. At the bank. Because the process is a transfer, a cash bank, right, $R T R W$, every device, all transfers. Unless this BPD incentive is still in cash, concerning the receipt, we give afterwards, one day after the disbursement we coordinate with the kasun to be checked and coordinated with RT and $R W . " \prime \prime$

All village income and expenditure in the context of implementing village authority is carried out through the Village Cash Account (RKD). All village income and expenditure transactions must be supported by complete and valid evidence and signed by the Village Head and Treasurer [12]

\section{Responsibilities of Village Fund Allocation (ADD)}

The responsibility for Village Fund Allocation (ADD) is integrated with the responsibility report for the realization of the Village Budget. Jember Regent Regulation Number 37 of 2019 concerning Procedures for the Distribution, Determination of Details and Guidelines for the Management of Village Fund Allocation in Jember Regency for the 2019 Fiscal Year also explains that the responsibility report for the realization of the APBDesa is submitted by the village head to the sub-district no later than three months after the end of the budget year regarding the stipulated by Village Regulation.

The ADD report consists of monthly reports and first semester reports. The first-semester report consists of the APBDesa implementation report and the ADD activity realization report. The village head has an obligation to submit a semester report no later than the second week of July (Permendagri 113, 2014).

The results of the interview show that the Jenggawah Village government has carried out the responsibility stage in accordance with the Minister of Home Affairs Regulation Number 113 of 2014. The form of reporting made by the Jenggawah Village Government includes semester reports, then the accountability report for the realization of the APBDesa implementation is supported by explanations from Informant 1:

"So for the accountability, it starts from the first-semester report and the final semester or two, if the first semester is per July, and for the second semester it is early January of the following year as well as the responsibility report for the preparation of the responsible Perdes for the last fiscal year."

Informant 1 also stated that during the reporting period, there were no obstacles encountered because the form of reporting was only limited to reporting without any supporting data. In preparing reports for reports per semester, Jenggawah Village held a Musdes for reporting on the use of the first and second-semester budgets, but for Perdes the accountability was not held a Musdes because the Village Government directly reported to the BPD, according to the results of the interview with Informant 1:

"There are actually no obstacles because what we report is limited to reporting, not all the supporting data, the reports per semester are usually held musdes reporting the use of the budget for semesters one and two but for 
village regulations on accountability there is no musdes so village government accountability reports to BPD."

All activities and programs funded by ADD are planned, implemented and evaluated openly by involving the village community. Thus the Jenggawah Village Government is obliged to carry out ADD fund management with the principles of transparency and accountability.

Jenggawah Village has implemented the principles of accountability and transparency in its accountability process. This can be seen from the Informant's statement 2:

"For transparency, we have a banner in front of you, on the banner, we will inform you about the amount of $A D D$ obtained and what programs will be implemented and then there will also be the realization, but for the realization of the 2019 budget yesterday it collapsed, miss, so there is no banner in front of it. "

The statement from informant 2 is in accordance with and consistent with the statement of informant one which explains that transparency will be done through a banner that will be placed on the front page of the village office but has collapsed and there has been no improvement.

\section{CONCLUSION}

Planning for the Village of Jenggawah starts from the Hamlet Deliberation in each hamlet, Musdes, the preparation of the RKP adopted from the RPJMDes is broadly in accordance with the Minister of Home Affairs Regulation Number 113 of 2014. The planning stage does not experience any obstacles in the process, the people of Jenggawah Village are also very enthusiastic about participating in every deliberation that is carried out and active in providing aspirations regarding the proposed programs and activities to be implemented so that the Jenggawah Village government can respond to the needs of residents. Thus, based on the Minister of Home Affairs Regulation Number 113 of 2014, the planning of Jenggawah Village can be said to be accountable and upholds citizen participation.

The implementation and administration stages of Jenggawah Village in managing ADD are structurally determined in accordance with the Minister of Home Affairs Regulation Number 113 of 2014. Even though in terms of implementation in the field it is not $100 \%$ in accordance with the roles and responsibilities of each coordinator due to the lack of human resources in the implementation of management ADD, but Jenggawah Village can overcome this problem by providing mutual assistance in one PTPKD team. Jenggawah Village has successfully implemented Law Number 6 of 2014 because it always involves the community from the procurement of goods and services to implementation, Jenggawah Village also carries out all programs and activities using a Payment Order under the Regulation of the Minister of Home Affairs Number 113 of
2014. Thus, based on the Minister of Home Affairs Regulation No. 113 of 2014 and Law No. 6 of 2014, Jenggawah Village is accountable, and there is community participation in it.

The accountability stage of Jenggawah Village has used the accountability report format under the Minister of Home Affairs Regulation Number 113 of 2014, and there are no obstacles in reporting. The entire process, from planning, implementation, to reporting, has been carried out accountably under regulations and always involves the participation of residents. Thus, based on the Regulation of the Minister of Home Affairs No. 113/2014, Desa Jenggawah has been said to be accountable, transparent, and has successfully implemented the principle of participation.

\section{ACKNOWLEDGMENT}

Thanks are conveyed to all parties who helped carry out this research well. The first gratitude goes to the Jember State Polytechnic, which has provided support ranging from licensing, administration, and research funding. Acknowledgments are then given to the head of the Jenggawah village and the village officials in Jember Regency who are willing to become respondents in this study.

\section{REFERENCES}

[1] F. B. Magur, "Implementasi Program Alokasi Dana Desa dalam Penyelenggaraan Pemerintahan di Desa Muruona," J. Keuang. Drh., 2011.

[2] BPKP, "Petunjuk pelaksanaan bimbingan \& konsultasi pengelolaan keuangan desa," 2015.

[3] R. Indonesia, Government Regulation Number 72 of 2005. 2005.

[4] R. Indonesia, Village Law No. 6 of 2014. 2014.

[5] S. A. Wida, D. Supatmoko, and T. Kurrohman, "Akuntabilitas Pengelolaan Alokasi Dana Desa (ADD) di Desa-Desa Kecamatan Rogojampi Kabupaten Banyuwangi," E-Journal Ekon. Bisnis Dan Akunt., vol. 4, no. 2, pp. 148-152, 2017

[6] J. Dura, "Pengaruh akuntabilitas pengelolaan keuangan alokasi dana desa, kebijakan desa, dan kelembagaan desa terhadap kesejahteraan masyarakat," J. Ilm. Bisnis dan Ekon. Asia, vol. 10, no. 2, pp. 26-32, 2016.

[7] E. Astuty, "Akuntabilitas Pemerintah Desa dalam Pengelolaan Anggaran Pendapatan dan Belanja Desa (APBDES)(Studi pada Alokasi Dana Desa Tahun Anggaran 2011 di Desa Sareng Kecamatan Geger Kabupaten Madiun)," Publika, vol. 1, no. 2, 2013.

[8] R. Fajri, "Akuntabilitas Pemerintah Desa pada Pengelolaan Alokasi Dana Desa (Studi Pada Kantor Desa Ketindan, Kecamatan Lawang, Kabupaten Malang)," J. Adm. Publik, vol. 3, no. 7, pp. 1099-1104, 2015.

[9] M. N. Aziiz and S. D. Prastiti, "Faktor-Faktor yang Mempengaruhi Akuntabilitas Dana Desa," J. Akunt. Aktual, vol. 6, no. 2, pp. 334344,2019

[10] R. N. Fathah, "Akuntabilitas Pengelolaan Alokasi Dana Desa (Studi Kasus Pengelolaan Alokasi Dana Desa di Desa Wijirejo Kecamatan Pandak Kabupaten Bantul Tahun 2016/2017)," JIAI (Jurnal Ilm. Akunt. Indones., vol. 2, no. 2, 2017.

[11] ---------, Jember Regent Regulation Number 37 of 2019. 2019.

[12] R. Indonesia, The Minister of Home Affairs Regulation Number 113. 2014. 